\title{
Research Advances on Experimental Biology of Woody Plants of A Tamaulipan Thorn Scrub, Northeastern Mexico and Research Needs
}

\author{
Ratikanta Maiti ${ }^{1}$, Humberto Gonzalez Rodriguez ${ }^{2 *}$, Aruna Kumari ${ }^{3}$ and N. C. Sarkar ${ }^{4}$ \\ 1,2 Universidad Autónoma de Nuevo Leon, Facultad de Ciencias Forestales, Carr. Nac. No. 85 Km. 45, Linares, \\ Nuevo Leon (67 700), Mexico \\ ${ }^{3}$ Crop Physiology, Professor Jaya Shankar Telangana State Agricultural University, Agricultural College, Polasa, \\ Jagtial, Karimnagar (505 529), India \\ ${ }^{4}$ Dept. of Agronomy, Institute of Agriculture, Visva-Bharati, PO- Sriniketan, Birbhum (Dist), West Bengal (731 236), India
}

Article History

Manuscript No. AR1632a

Received in $1^{\text {st }}$ July, 2016

Received in revised form $25^{\text {th }}$ September, 2016

Accepted in final form $6^{\text {th }}$ October, 2016

\section{Correspondence to}

"E-mail: humberto.gonzlez@uanl.mx

\section{Keywords}

Woody plants, anatomy, ecophysiology, pigments, adaptation, xeric environments

\begin{abstract}
The present review makes a synthesis of various aspects of applied biology of more than 30 woody plant species of a Tamaulipan Thorn scrub, Northeastern Mexico. This deals with the biodiversity of leaf traits, leaf anatomy, plant characteristics, wood anatomy, wood density, phenology and few aspects of physiology and biochemistry viz., leaf pigments, leaf epicuticular wax, trees with high nutritional values, carbon fixation, nitrogen and protein contents. The results show a large variability of all the morpho-physiological traits of the woody species related to the co-existence and adaptation of the woody species in semiarid environments. Special emphasis has been given to discuss the role of various morpho-anatomical and ecophysiological traits for adaptation to xeric environments such leaf anatomical traits (leaf surface, leaf lamina, petiole, venation system) and wood anatomical traits and few ecophysiological traits suchas pigments, epicuticular wax, leaf nutrients, carbon fixation etc., which could be related to the adaptation of the species in xeric environment. Different woody species possess specific adaptive mechanisms in a forest ecosystem. This also suggests research needs and put forward few hypotheses for efficient management of forest system. No such inter-disciplinary studies are available on Tamaulipan Thorn scrub.
\end{abstract}

\section{Introduction}

Forests play a great role in offering great service to mankind in reducing carbon dioxide from the atmosphere and converting it to carbon in wood as source of energy through the process of photosynthesis and supply domestic and industrial products and function as source of nutrients to grazing animals. Therefore, forests are saviors of our lives, thereby urging the need of conservation of trees and shrubs in forests. In a forest ecosystem different species of woody plants grow together in a harmony in sharing solar radiation through the process of photosynthesis and exchange of gases in the above ground atmosphere and absorbing water and nutrients through roots distributed at soil depths. There is a great necessity of research inputs on woody plant species.

During few years we have made reasonable progress on various aspects of experimental biology of more than 30 woody species in a Tamaulipan Thorn Scrub, at Linares, Northeastern Mexico. We give here a synopsis of research results. Different species possess various adaptative mechanisms for co-existence in a forest ecosystem (Maiti and Rodriguez, 2015c; Maiti et al., 2016a). Intensive literatures on various aspects of woody trees and shrubs are well documented in two books (Maiti et al. 2016 ed). This makes a brief synthesis of papers published, few in press and few unpublished ones. Research needs and few hypotheses are put forward.

\section{Tree Species under Study}

We adopted standard protocol for studying different aspects of applied biology.

Data were taken on the following species (Table 1).

\section{Leaf Traits}

Leaves play an important role in the capture of carbon dioxide through the photosynthetic process and exchange gases for plant metabolism. There exists great diversity in leaf shape, size among woody species for co-existence. The 


\begin{tabular}{|c|c|c|c|c|c|c|c|}
\hline \multicolumn{4}{|c|}{ Table 1: Woody plants used for research. } & \multirow[b]{2}{*}{$\begin{array}{l}\text { Sl. } \\
\text { No. }\end{array}$} & \multirow[b]{2}{*}{ Scientific name } & \multirow[b]{2}{*}{ Family } & \multirow[b]{2}{*}{ Type } \\
\hline $\begin{array}{l}\text { Sl. } \\
\text { No. }\end{array}$ & Scientific name & Family & Type & & & & \\
\hline 1. & Acacia berlandieri Benth. & Fabaceae & tree & 21. & Forestiera angustifolia & Oleaceae & shrub \\
\hline 2. & Acacia farnesiana (L) Willd & Fabaceae & tree & & Torr. & & \\
\hline 3. & Acacia rigidula Benth. & Fabaceae & tree & 22. & Fraxinus greggii A. Gray & Oleaceae & tree \\
\hline 4. & $\begin{array}{l}\text { Acacia schaffneri (S. Wat- } \\
\text { son) F.J. Herm }\end{array}$ & Fabaceae & shrub & 23. & $\begin{array}{l}\text { Guaiacum angustifolium } \\
\text { Engelm }\end{array}$ & $\begin{array}{l}\text { Zygophylla- } \\
\text { ceae }\end{array}$ & shrub \\
\hline 5. & Acacia wrightii Benth. & Fabaceae & tree & 24. & Gymnosperma glutinosum & Asteraceae & shrub \\
\hline 6. & Amyris texana (Buckley) P. & Rutaceae & shrub & & (Spreng.) Less & & \\
\hline & Wilson & & & 25. & Havardia pallens (Benth.) & Fabaceae & tree \\
\hline 7. & Berberis chococo Schlecht & Berberidaceae & tree & & Britton \& Rose & & \\
\hline 8. & $\begin{array}{l}\text { Bernardia myricifolia } \\
\text { (Scheele) Benth. \& Hook. F. }\end{array}$ & Euphorbiaceae & shrub & 26. & $\begin{array}{l}\text { Helietta parvifolia (A. } \\
\text { Gray) Benth }\end{array}$ & Rutaceae & tree \\
\hline 9. & $\begin{array}{l}\text { Caesalpinia mexicana A. } \\
\text { Gray }\end{array}$ & Fabaceae & tree & 27. & $\begin{array}{l}\text { Karwinskia humboldtiana } \\
\text { (Schult.) Zucc. }\end{array}$ & Rhamnaceae & shrub \\
\hline 10. & Celtis laevigata Willd & Ulmaceae & tree & 28. & Lantana macropoda Torr. & Verbenaceae & shrub \\
\hline 11. & Celtis pallida Torr & Ulmaceae & shrub & 29. & Leucaena leucocephala (J. & Fabaceae & tree \\
\hline 12. & Cercidium macrum I.M. & Fabaceae & tree & & de Lamarck) H. C. de Wit & & \\
\hline 13. & $\begin{array}{l}\text { Johnst } \\
\text { Condalia hookeri M. C. }\end{array}$ & Rhamnaceae & shrub & 30. & $\begin{array}{l}\text { Leucophyllum frutescens } \\
\text { (Berland) I.M. Johnst }\end{array}$ & $\begin{array}{l}\text { Scrophularia- } \\
\text { ceae }\end{array}$ & shrub \\
\hline 14. & $\begin{array}{l}\text { Johnst } \\
\text { Cordia boissieri A. DC. }\end{array}$ & Boraginaceae & tree & 31. & $\begin{array}{l}\text { Prosopis laevigata (H. \& } \\
\text { B.) Jonhst }\end{array}$ & Fabaceae & tree \\
\hline 15. & Croton suaveolens Presl. & Euphorbiaceae & shrub & 32. & Quercus virginiana Mitl. & Fabaceae & tree \\
\hline 16. & Diospyros palmeri Eastw & Ebenaceae & tree & 33. & Retama sphaerocarpa (L.) & Fabaceae & shrub \\
\hline 17. & Diospyros texana Scheele & Ebenaceae & tree & & Boiss & & \\
\hline 18. & $\begin{array}{l}\text { Ebenopsis ebano (Berland.) } \\
\text { Barneby \& J.W. Grimes }\end{array}$ & Fabaceae & tree & $\begin{array}{l}34 . \\
35 .\end{array}$ & $\begin{array}{l}\text { Salix lasiolepis Benth. } \\
\text { Sargentia greggii S. Wats }\end{array}$ & $\begin{array}{l}\text { Salicaceae } \\
\text { Rutaceae }\end{array}$ & $\begin{array}{l}\text { tree } \\
\text { tree }\end{array}$ \\
\hline 19. & $\begin{array}{l}\text { Ehretia anacua (Teran \& } \\
\text { Berland.) I.M. Johnst }\end{array}$ & Boraginaceae & tree & 36. & $\begin{array}{l}\text { Sideroxylon celastrinum } \\
\text { (Kunth) T.D. Penn }\end{array}$ & Sapotaceae & tree \\
\hline 20. & $\begin{array}{l}\text { Eysenhardtia polystachya } \\
\text { Ortega, Sarg. }\end{array}$ & Fabaceae & shrub & 37. & $\begin{array}{l}\text { Zanthoxylum fagara (L.) } \\
\text { Sarg. }\end{array}$ & Rutaceae & shrub \\
\hline
\end{tabular}

native species Cordia boissieri, Condalia hookeri, Sargentia greggii, Diospyros texana, Zanthoxylum fagara, Sideroxylon celastrinum, Karwinskia humboldtiana, Celtis pallida, Guaiacum angustifolium, Prosopis laevigata, Celtis laevigata, Parkinsonia texana, Forestiera angustifolia and Havardia pallens were chosen due to their ecological and economic importance to the rural villages as well as large variability in morphological characteristics between them (Maiti et al., 2014a).

A study was undertaken in variation in leaf traits of 34 Trees and Shrubs in Summer Season in Linares, North-Eastern Mexico. The results revealed that there exists large variations in leaf area $\left(\mathrm{cm}^{2}\right)$, specific leaf area $\left(\mathrm{cm}^{2} \mathrm{~g}^{-1}\right)$ and leaf dry mass $(\mathrm{g})$, petiole length and moisture content both in Winter

and Summer seasons. Leaf area $\left(\mathrm{cm}^{2}\right)$ ranged from 0.733 to $215.926\left(\mathrm{~cm}^{2}\right)$, leaf dry mass from 0.006 to $1.463(\mathrm{~g})$, specific leaf area from 11.833 to $1982.780\left(\mathrm{~cm}^{2} \mathrm{~g}^{-1}\right)$, leaf length from 0.700 to $51.00(\mathrm{~cm})$, leaf breadth from 0.400 to $22.400(\mathrm{~cm})$ and petiole length from 0.100 to $13.00(\mathrm{~cm})$. Leaf area showed highly significant positive correlations with leaf dry weight (g) $(\mathrm{r}=0.94)$, leaf length $(\mathrm{r}=0.88)$, leaf breath $(\mathrm{r}=0.807)$, and petiole length $(\mathrm{r}=0.71)$ while the leaf dry weight showed highly significant correlation with leaf length $(\mathrm{r}=0.88)$, leaf breadth $(\mathrm{r}=0.775)$, and petiole length $(\mathrm{r}=0.734)$. Specific leaf area did not show any significant correlations with any of the variables studied. Therefore, leaf area, leaf length, petiole length has significant roles in plant productivity and reveals that there exists interspecific diversity among distinct leaf characteristics 
which in turn determine distinct functional trends among the community studied (Rodriquez et al., 2015c).

Woody plants possess two types of leaves, open canopy (all leaves exposed to sunlight), others close canopy where all leaves are not exposed to sunlight for capture of solar radiation. It is hypothesized that variability in Leaf Canopy Architecture may be Related to Photosynthetic Efficiency and Carbon Fixation (which needs to be confirmed in future study (Maiti et al., 2014b).

Maiti et al. (2016d) made a synthesis of biodiversity of leaf traits of native woody species of aTamaulipan Thorn Scrub.

\subsection{Leaf anatomy}

Leaf anatomical structures such as leaf surface, leaf lamina, petiole venation pattern plan important roles in the taxonomic delimitation and adaptation of the woody plants to xeric habitats in Northeastern Mexico.

\subsubsection{Leaf surface anatomy}

A comparative study has been undertaken on leaf surface (dermal) anatomy of 28 species of trees and shrubs of Tamaulipan Thorn Scrub, Northeastern Mexico and its possible relation with drought resistance (unpublished). The species have been classified on the basis of various traits which can be used in species delimitation and adaptation to the semiarid condition such as waxy leaf surface, absence or sparse stomata on the leaf surface, sunken stomata. The species identified as better adapters to semi arid environments on the basis of the presence and absence of stomata on both adaxial and abaxial surface such as., Berberis chococo, Celtis laevigata, Condalia hookeri, Diospyros palmeri, Diospyros texana, Ebenopsis ebana, Ehretia anacua, Forestieria angustifolia, Havardia pallens, Helieta parviflora, Karwinskia humboldtiana, Sargantia gregii, Sideroxylon celastriana, Zanthoxylum fagara. The water relations and drought resistance of the species mentioned should be confirmed in future study.

\subsubsection{Anatomy of leaf lamina}

A study was undertaken to determine the variability in leaf anatomical traits and its relation to taxonomic delimitation and adaptation of the woody species in xeric environments in semiarid conditions in Northeastern Mexico. The results show large variability in anatomical traits with respect to cuticle thickness, presence and absence of trichomes, length of palisade cells and thickness of spongy tissue. Species have been classified on the basis of the length and compactness of palisade cells to determine its relation to the taxonomic delimitation and the adaptation of the species to drought condition. The species viz., Karwinskia humboldtiana, Lantana macropoda, Prosopis laevigata, Zanthoxylum fagara, Helietta parvifolia, Acacia berlandieri and Acacia wrightii having long and compact palisade cells are expected to be efficient in photosynthetic function and adaptation to drought. Future research needs to be directed in this direction (Maiti et al., unpublished).

\subsection{Petiole anatomy}

Petiole plays an important role in holding and exposing leaf lamina to solar radiation, in the transport of water and nutrients and offering mechanical strength against environmental stresses.

A comparative study on petiole anatomy of 36 woody species has revealed the presence of a large variability among species in various anatomical traits which can be used in taxonomic delimitation. Species were grouped on the basis of various petiole anatomical traits. In addition several species are selected for few desirable traits. Only five species are mentioned for each desirable trait such as those having large vascular bundle are efficient in the transport of nutrients and water viz., Acacia berlandieri, Acacia rigidula, Diospyros palmeri, Fraxinus greggii, Guaiacum angustifolia, thick petiole (Acacia berlandieri, Acacia farnesiana, Berberis chococo, Bernardia myricifolia, Eysenhardtia texana) and mechanical tissues such as thick cuticle (Acacia berlandieri, Celtis pallida, Condalia hookeri, Eysenhardtia texana, Gymnosperma glutinosum, a thick collenchyma (Acacia farnesiana, Berberis chococo, Bernardia myricifolia, Celtis pallida, Havardia pallens) and extra sclerenchyma bands that offer mechanical strength (Acacia berlandieri, Ebenopsis ebano, Eysenhardtia texana, Lantana macropoda, Prosopis laevigata, Xanthoxylum fagara). The species having the combination of various desirable traits are expected to be more efficient in the physiological function and mechanical support. In this respect we can mention Acacia berlandieri as an ideal species.

\subsection{Venation pattern and venation system}

Venation patterns in leaves represent typical vascular skeleton in a leaf lamina offering mechanical function and transport of water, carbohydrates in plants. A study was undertaken on venation pattern and venation density of few trees and shrubs. At first the venation pattern of 30 species has been classified according to the system of Hickey (1971). Among the 30 species studied 28 species belong to Brochidodromous: while only two species belong to Craspedodromous. In the second stage, the venation architecture andvenation density of only 20 species were undertaken following the clearing technique by keeping the leaves in test tubes in solutions of $\mathrm{H}_{2} \mathrm{O}_{2}: \mathrm{NH}_{4} \mathrm{OH} 50$ for time necessary to achieve whitening leaf rib and observed in the microscope at $5 \mathrm{X}$. The species showed large variations in venation architectures in orientation, 
size, shape depicting the characteristics of each species. The species also showed variation indensity of vein. Islets in few species are bounded by thin veins but traversed by thickervein to give mechanical strength to the leaf lamina against stress showing, adaptive characteristics. Among the species studied Eysenhardtia texana had maximum veinislet density, Ebenopis ebano, Caesalpinia mexicana, Karwinskia humboldtiana, etc. possessed medium density, while Guaiacum officinale, Amyris madrensis, Sargentia greggii, had low density. There is a necessity to characterize venation system of more trees and shrubs and relate it to the productivity of the species (Maiti et al., 2015h).

\section{Plant Characteristics and Relationship}

Woody plant species possess various plant characteristics such as type of leaf canopy,tree crown architecture, plant height, canopy cover, basal diameter, branching patterns and branching density and there exists relationships among these parameters. There exists significant variations in plant parameters and their correlations among species (Maiti et al., 2015d).

\subsection{Tree crown}

Every tree species possesses a typical tree top crown architecture such as globose, round, irregular architecture with the association of branches and leaves which help in the capture of solar radiation. Few studies have been undertaken in these aspects.

\subsubsection{Branching pattern and branching density}

Branching pattern and crown architecture are the important component of plant growth and development of any plant species. The leaf area and photosynthesis efficiency mainly depended on the crown architecture. Here, the research findings in this respect pertaining to the shrubs and tree species of the North East Mexico has been reviewed. The branching habit has been classified as monopodial, sympodial and pseudomonopodial, while the crown architecture as globose and irregular (Maiti et al., 2015e).

A study has been undertaken on the perspectives of branching pattern and branching density in 30 woody trees and shrubs in Tamulipan Thornscrub, Northeast of Mexico. The branching pattern functions as solar panel in the capture of solar radiation for the production of biomass and timber. A study was undertaken with the objective of determining the density of branching and types of branching of 30 tree species (trees and shrubs of Tamaulipan thorn scrub such; Helietta parvifolia, Sargentia gregii, Guaiacum angustifolium, Ebenopsis ebano, Harvadia pallens, Condalia hoockeri, Zanthoxylum fagara, Cordia boissieri, Acacia berlandieri, Diospyros texana, Celtis pallida, Forestiera angustifolia, Diospyros palmeri, Parkinsonia texana, Acacia farnesiana, Sideroxylon celastrina, Caesalpinia mexicana, Karwinskia humboldtiana, Croton suaveolens, Amyris texana, Leucaena leucocephala, Ehretia anacua, Gymnosperma glutinosum, Celtis laevigata, Acacia rigidula, Acacia shaffneri, Eysenhardtia polystachya, Prosopis laevigata, Bernardia myricifolia and Leucophyllum frutscens. The types of branching observed are; monopodial, pseudomonopodial, and sympodial. The branching density observed through animation photography in the field has revealed the presence of three types branching density i.e., high, medium and low density. There existed differences in height, biomass, basal trunk, the angle of the primary and secondary branches. With respect to branching density, a higher number of species were high density (15 species), followed by low density (9) and medium density (5 species). The architecture of the tree is the result of the activity of the apical and axial meristems. This model is a strategy for occupying the space and capture of solar radiation (Maiti et al., 2015d).

\subsection{Wood anatomy}

Wood is an industrial product of great economic importance derived from cambial activity in a tree. Wood is composed of secondary xylem vessels, wood fibres, wood parenchyma and other products. Significant research inputs have been documented on wood anatomy.

A study has been undertaken on wood anatomy of 20 woody species in northeast Mexico. There exists large variation among species in wood anatomical traits such as porosity, vessel diameter, its distribution, parenchyma, compactness of ground tissues and fibre cell characteristics. Most of the species have narrow vessels which help protection against cavitation. Most of the species are ring to semiring porous viz. Acacia amentacea, Acacia berlandieri, Acacia shaffneri, Acacia wrightii, Cordia boissieri, Helietta parviflora, Condalia hookeri, Xanthoxylum fagara, Celtis pallida, Celtis laevigata, Caesalpinia mexicana, Eysenhardtia polystachya; only few of them are diffuse porous viz. Diospyros palmeri, Diospyros texana. Fibre cell characteristics also showed large variations in morphology, size, lumen breadth and in compactness, these species were soft and hard wood. Most of the species have narrow vessels, viz., Acacia berlandieri, Acacia shaffneri, Acacia wrightii, Helietta parviflora, Cordia boissieri, Diospyros palmeri, Celtis laevigata, Eysenhardtia polystachya, Xanthoxyllum fagara. Celtis pallida contained medium sized vessels, while Celtis laevigata and Caesalpinia mexicana possessed big sized vessels. Many of the species possess narrow vessels which although impose transport of water but protect the vessels against cavitation during drought and freezing the species with small narrow vessels mentioned have 
strategy to adapt both to hot and cold climate against cavitation. The species having big vessel diameter may be susceptible to drought such as Celtis pallida, Caesalpinia mexicana or they may have deep root system for adaptation to semiarid climates in northeast Mexico. All these wood anatomical traits could be utilized to distinguish species as well as quality determinations of species. The variation in hydraulic systems determine the capacity of water transport among species. Statistically significant differences are observed in all wood anatomical parameters among species studied. In addition a study has been made on wood anatomy of 33 woody trees and shrubs showing a large variability in wood anatomical traits which may be used in the taxonomic delimitation and adaptation of the species toxeric environments. It has been documented in the literatures that the species having narrow vessels acts against cavitation and embolism during hot summer, in which direction research needs to be directed to confirm it further in semiarid regions of Northeastern Mexico.

In addition, a comparative studyhas been undertaken on wood anatomy of 12 woody species at Linares, northeast Mexico. The results show large variation among species in wood anatomical traits such as porosity, vessel diameter, its distribution, parenchyma, compactness of ground tissues and fibre cell characteristics. Most of the species are ring to semiring porous viz., Acacia shaffneri, Acacia wrightii, and Eysenhardtia polystachya. Fibre cell characteristics also showed large variations in morphology, size, lumen breadth and in compactness, these species were soft and hard wood. Most of the species have narrow vessels, viz., Acacia shaffneri, Acacia wrightii, Helietta parvifolia, contained medium sized vessels. Many of the species possess narrow vessels which although impose transport of water but protect the vessels against cavitation during drought and freezing the species with small narrow vessels mentioned have strategy to adapt both to hot and cold climate against cavitation. All these wood anatomical traits could be utilized to distinguish species as well as quality determinations of species. The variation in hydraulic systems determine the capacity of water transport among species (Gonzalez Rodriguez et al., not published).

A study was undertaken to determine the variability in fiber cell morphology and its length among wood species of the Tamaulipan thornscrub, northeastern Mexico, used for various uses such as timber for furniture, fence, post, firewood and sources of forage. The results show large variability in fiber cell morphology and fiber cell length.The species have been classified on the basis of its fiber cell morphology and fiber cell length and recommended fortheir possible utilization for different purposes. This technique can be used in preliminary screening of woody speciesfor its utilization for different purposes. Further studies are needed to confirm (Maiti et al., 2015f).

It has been observed that the species having high value of length/breadth ratio of fibre cells are expected to produce strong wood fibres were: Ehretia anacua $(55.77 \mu \mathrm{m})$, Quercus polymorpha $(51.71 \mu \mathrm{m})$, Helietta parvifolia $(41.85 \mu \mathrm{m})$, Prosopis laevigata $(38.31 \mu \mathrm{m})$, Celtis laevigata $(37.28 \mu \mathrm{m})$, Acacia farnesiana $(33.95 \mu \mathrm{m})$, Celtis pallida $(33.45 \mu \mathrm{m})$, Gochnatia hypoleuca $(32.67 \mu \mathrm{m})$, Karwinskia humboldtiana $(32.36 \mu \mathrm{m})$ and Cordia boissieri $(31 / 47 \mu \mathrm{m})$. These could be recommended for paper pulp manufacture also. Species having broad breadth are expected to be desirable for paper pulp production. Species having high wall thickness are expected to produce strong fibre for high lignification. The results on fibre dimensions in the present study coincide with the findings by several authors mentioned before for its possible utility with respect to variability in fibre cell dimensions and lignin content.

It has been hypothesized that wood Anatomy could predict the adaptation of woody plants to environmental stresses and quality of timbers (Maiti and Rodriguez, 2015d).

\subsection{Wood density}

A preliminary study has been undertaken for wood density and its utilization in northeastern Mexico for different purposes and to find possible relationship of density with wood fibre characteristics. The results reveallarge variability in wood density and in fibre cell morphology. The species have been classifiedon the basis of wood density and its fiber cell morphology and has been recommended for their possible utilization for different purposes.

Species desirable for strong furniture making, paper pulp, soft furniture, fence etc. can be selected on the basis of fibre length to breadth ratios as strong fibres for furniture and fibre cells with broad lumen and thin cell wall use for fabrication of paper pulp and other utilities.

Subsequently a study has been undertaken by Maiti et al. (2016c) on variability of Wood density and its possible relation to few wood chemical composition and wood fiber cell structure anatomy. The results revealed that among 10 species studied, there exist a large variation in wood density ( 0.51 to 1.09 ), and few wood chemical composition such \% carbon (37.14 to 44.07$)$, nitrogen (9.18 to 19.22 ), sulphur (31.45 to 33.82), lignin (15.28 to 24.35), hemicellulose (19.94 to $27.36 \%$ ), and \% cellulose (33.69 to 45.92 ). In general, though there was noclear relationship between wood density and other chemical composition of wood. It was observed that the species having moderate to high wood density contained $>40 \%$ carbon, $>30 \%$ sulphur and $>40 \%$ cellulose and more or less $20 \%$ lignin. It seems that carbon, sulphur, cellulose and 
lignin contents contribute to greater density. The wood fiber cell with wall lignification seemsto be related to higher wood density (Maiti et al., 2016d).

\section{Reproductive Biology}

In a forest ecosystem trees and shrubs start flowering, fruitification and finally disperse seeds for maintenance of their life cycles. It is necessary to know these phenomenon for the foresters for effective management of the forest. A study has been made by Rodriguez and Maiti (2015b) to determine flowering and fruiting phenology of 12 woody species in Linares, Northeast of Mexico during the period from March to December 2013. The most representative species are: Prosopis laevigata (Humb. and Bonpl ex Willd.). M.C Johnst, Ebenopsis ebano (Berland.) Barneby and J.W Grimes, Acacia amentacea D.C., Castela erecta Turpin sub sp texana (Torr. and A. Gray) Cronquist, Celtis pallida Torr., Parkinsonia texana var. Macra (IM Johnst.) Isely, Forestiera angustifolia Torr., Cordia boissieri A.DC., Leucophyllum frutescens (Berland.) IM Johnst., Guaiacum angustifolium Engelm., Cylindropuntia leptocaulis (DC.) F.M Knuth, Opuntia spp, Zanthoxylum fagara Sarg., Sideroxylon celastrinum (Kunth) T.D. Penn, Helietta parvifolia (A. Gray ex Hemsl) Benth., among others. The species were selected on the basis of ecological and nutritional value for livestock and wild ruminant animals and multiple uses of shrubs. There exists a large variability in the phenological stages among species. The first study was concentrated on the basis of the percentage of different phenological stages. The second study was mainly concentrated on the time of appearance of each phenological stage in individual species. The results clearly demonstrate about the variation in phenological time schedule among different species. Very little studies have been undertaken in this aspect in the literature. Therefore, there is a need to evaluate the phenology of each individual species. This knowledge will help forest managers for efficient management of the forest as well as the time of seed production of the species of seeds.

A study has been made on phenology and pollen viability of four woody species revealing that temperature play an important role on pollen viability (Maiti and Rodriguez, 2015a).

\section{Physiology and Biochemistry}

\subsection{Leaf pigments}

Woody plant species possess different pigments such as cholorophyll a, chlorophyll b, carotenoids and other pigments among which chlorophyll helps in the absorption of solar energy during the process of photosynthesis.
A study has been made on pigment contents (Chlorophyll and Carotenoid) in 37 species of Trees and Shrubs in Northeast of Mexico during summer season. Large variations were observed in the contents of chlorophyll (a, and b and total) and also carotenoids among species. Chorophyll a was minimum in Leucophyllum frutescens, Acacia berlandieri contained (around $0.6 \mathrm{mg}$ ), maximum was observed in Leucaena leucocephala (nearing $1.8 \mathrm{mg}$ ). Chlophyll b was mínimum in Foresteria angustifolia, Acacia berlandieri, Acacia palmeri, Leucophyllum frutescens ( 0.1 to $0.2 \mathrm{mg}$ ), while Leucaena leucocephala contained maximum $(0.4 \mathrm{mg})$. Carotenid content was minimum (around $0.2 \mathrm{mg}$ ) were in Eysenhardtia polystachya, Guaicum angustifolia, Leucophyllum frutescens and others but maximum value was observed in Croton suaveolens. Total chlorophyll was minimum values (around 0.5 $\mathrm{mg}$ ) in Leucophyllum frutescens, Helietta parviflora, Lantana macropoda, Foresteria angustifolia, Croton suaveolens, while máximum value (around $2 \mathrm{mg}$ ) was obtained in Leucaena leucocephala. Chlorophyll (a, b) ratio Foresteria angustifolia, Parkinsonia aculeata showed maximum value (around 7) followed by Diospyros texana (around 6). Chlorophyll total/ carotenoids $a$ showed maximum value (nearing 8), while minimum value was obtained in E. trifoliata (around 1). There is a necessity to study photosynthetic efficiency and productivity of the woody species with high pigment contents.

In a study there exists seasonal variation of leaf pigments in trees and shrubs in summer and Winter seasons, the species contained lower pigments during Winter seasons (Maiti et al., 2016d-American Academic press).

In the context of the results it may be interpreted that the species showed variations in various pigment contents in both winter (February, 2015) and Summer, (June 3), few remaining more less stable, others showed decline while few showed increase. These variations in pigment contents could have direct or indirect effect on photosynthetic capacity and the productivity of the species studied which need to be confirmed in future study. It may be mentioned here that at the time of collection of leaf samples in February the temperature ranged from 2 to $3^{\circ}$, but few species did not show decline as mentioned above showing tolerance to cold temperature such as Sargentia greggii and Guiacum angustifolium (papers in press, IJBSM). Therefore, the climatic conditions and environments have influence on pigment contents and probable photosynthetic capacity. It may be interpreted that the increase in chl-a in Ebenopsis ebano and Leucaena leucocephala could be related to higher photosynthetic capacity in summer season. Similarly Eysenhardtia polystachya showing an increase in chl b could be related to higher photosynthetic capacity in summer season. Similarly, the increase in total chlorophyll content in Ebanopsis 
ebano and Leucaena leucocephala could be related to higher photosynthetic capacity in summer season. Our observations coincide with the findings of various authors who discussed the role of pigments in plant metabolism and plant productivity.

\subsection{Epicuticular wax}

Several woody species in the semiarid regions of Northeastern Mexico possess waxy leaf surface owing to the presence of epicuticular wax. It has been documented that epicuticular wax helps in the reflection of sunlight from the leaf surface, thereby reducing radiation load and maintaining lower leaf temperature which impart resistance to drought.

A study on the variability in epicuticular wax in 35 woody species in Linares, Northeast Mexico at the experimental station of Facultad de Ciencias Forestales, Universidad. Considerable variation in wax accumulation was found among species showing prominent interspecific variation. Wax load varied from 11.18 to $702.04 \mu \mathrm{g} \mathrm{cm}^{-2}$ among species studied during summer. Few species selected with high epicuticular wax viz, Forestiera angustifolia $\left(702.04 \mu \mathrm{g} \mathrm{cm}^{-2}\right)$, Diospyros texana $\left(607.65 \mu \mathrm{g} \mathrm{cm}^{-2}\right)$, Bernardia myricifolia $\left(437.53 \mu \mathrm{g} \mathrm{cm}^{-2}\right)$, Leucophylum leucocephala ( $\left.388.50 \mu \mathrm{g} \mathrm{cm}^{-2}\right)$, during summer which could well be adapted under semi-arid environments for their efficiency in the reflection of radiation load, reduced transpiration, gas exchange and probably impart drought resistance. The large variations in epicuticular wax could be related to their physiological functions such as transpiration, gas exchange, water relations etc (Maiti et al., 2015f).

\subsection{Macro and micronutrients}

Woody plants possess various leaf nutrients which help in the growth and development of the species and serve as sources of nutrients by the grazing animals.

Astudy was under taken to estimate six nutrients in the leaves, three macronutrients $(\mathrm{K}, \mathrm{Mg}, \mathrm{P})$ and three micronutrients $(\mathrm{Cu}, \mathrm{Fe}, \mathrm{Zn})$ of twenty five woody species in Linares, Northeastern of Mexico (Maiti et al., 2016d). Macronutrients and micronutrient contents $(\mathrm{Cu}, \mathrm{Fe}, \mathrm{Mn}, \mathrm{Zn}, \mathrm{Ca}, \mathrm{K}, \mathrm{Mg}, \mathrm{P}, \mathrm{C}$ and $\mathrm{N}$ ) of ten native species exhibit large variations among species in the contents of the nutrients. $\mathrm{K}$ values ranged from round about 6.80 to $75.62 \mathrm{mg} \mathrm{g}^{-1} ; \mathrm{Mg}$ content ranges 0.22 to $5.29 \mathrm{mg} \mathrm{g}^{-1}, \mathrm{P} 0.09$ to $2.43 \mathrm{mg} \mathrm{g}^{-1} \mathrm{Cu}$ from 0.09 to 2.8 to 30.71 $\mu \mathrm{g} \mathrm{gps}^{-1}$, Fe from 66.32 to $276 \mu \mathrm{gps}^{-1}, \mathrm{Zn}$ from 10.23 to 144.86 $\mu \mathrm{g} \mathrm{gps}^{-1}$. Croton suaveolens acquired highest level of $\mathrm{P}(2.43$ $\mathrm{mg} \mathrm{g}^{-1}$ ) and $\mathrm{K}\left(75.62 \mathrm{mg} \mathrm{g}^{-1}\right)$, whereas Parkinsonia aculeata for $\mathrm{Mg}\left(5.29 \mathrm{mg} \mathrm{g}^{-1}\right)$. Cordia boissieri for both $\mathrm{Cu}\left(30.71 \mu \mathrm{g} \mathrm{gps}^{-1}\right)$ and $\mathrm{Fe}\left(280.55 \mu \mathrm{g} \mathrm{gps}^{-1}\right)$, on the other hand, Salix lasiolepis for $\mathrm{Zn}\left(144.86 \mu \mathrm{g} \mathrm{gps}^{-1}\right)$. These species could serve as excellent sources for ruminants and could adapt and grow well for high nutrient contents. The values of mineral contents were much higher than required by the grazing ruminants.

Leaf nutrients play an important role for the growth and development of trees and are sources of nutrients for ruminants in forest. The present study was under taken to estimate six nutrients in the leaves, three macronutrients $(\mathrm{P}, \mathrm{Mg}, \mathrm{K}$, protein, $\mathrm{C}, \mathrm{N}, \mathrm{C} / \mathrm{N}$ and three micronutrients $(\mathrm{Cu}, \mathrm{Fe}, \mathrm{Zn})$. Among macronutrients $\mathrm{P}$ : varied from 0.78 to 243 ( $\mathrm{mg} \mathrm{g}^{-1}$ $\mathrm{dw}$ ), the species containing high $\mathrm{P}$ are Croton suaveolens 2.43, Eysenhardtia polystachya 1.84, Prosopsis laevigata1.65, Parkinsonia aculeata, 1.56, Acacia farnesiana 1.54, Mg (mg $\mathrm{g}^{-1} \mathrm{dw}$ ) varied from 0.22 to $9.45\left(\mathrm{mg} \mathrm{g}^{-1} \mathrm{dw}\right)$. The species containing high $\mathrm{Mg}\left(\mathrm{mg} \mathrm{g}^{-1} \mathrm{dw}\right)$ are E. anacua 9.45 , C. hookeri 6.50, P. aculeata 5.29 .

6.4. Biodiversity in leaf chemistry (Pigments, Epicuticular Wax and Leafmacro and micronutrients

6.4.1. A study has been made on pigments, epicuticular wax and macro and micronutrients of 15 woody species (Maiti et al., $2015 \mathrm{~g}$ )

The results of studies undertaken on more than 30 woody species in North-eastern Mexico revealed that there exists large variations in pigments (chlorophyll, carotenoids),epicuticular wax, macro and micro nutrients. Several species have been selected with high values of thepigments, epicuticular wax and various macro and micronutrients. For example, species with high Chlorophyll content were: Ebenopsis ebano (1.755), Croton suaveolens (0.589), Amyris texana (1.66), and those with high chlorophyllb were Ebenopsis ebano (0.398), Amyris texana (1.66) and species with high Chlorophyll total (Chl $\mathrm{a}+\mathrm{b})$ were: Ebenopsis ebano (2.253), Leucaena leucocephala (1.687). Species with high carotenoids were: Berberis chococo (0.585), Diospyros palmeri (0.433). The species showing high epicuticular wax load are Forestiera angustifolia (702.04 $\left.\mu \mathrm{g} \mathrm{cm}^{-2}\right)$, Diospyros texana $\left(607.65 \mu \mathrm{g} \mathrm{cm}^{-2}\right)$, Bernardia myricifolia $\left(437.53 \mu \mathrm{g} \mathrm{cm}^{-2}\right)$. There is a here aneed to confirm the efficiency of these selected species for productivity and adaptation of the species to environment.

6.4.2. Nutrients in woody plant species in North-eastern Mexico, a synthesis

The present paper makes a synthesis of two earlier studies undertaken on macro and micronutrients of 1) 37 woody species and 2) 44 medicinal plants used traditionally of Northeastern Mexico (Maiti et al., 2016c).

In the both the studies we estimated the contents of six nutrients in the leaves, three macronutrients $(\mathrm{P}, \mathrm{Mg}, \mathrm{K}$, protein, $\mathrm{C}, \mathrm{N}, \mathrm{C} / \mathrm{N}$ and three micronutrients $(\mathrm{Cu}, \mathrm{Fe}, \mathrm{Zn})$ both for woody species and medicinal plants. A large variability exists in nutrient contents in woody species and medicinal 
plants. The species selected for the highest macronutrients and micronutrients may be utilized for confirming their physiological efficiency and probable better growth and productivity as well as good sources of macro and micronutrients for grazing wild animals.

We selected Eco-physiologically Highly Efficient Woody Plant Species in Northeastern Mexico (Maiti and Rodriguez, 2015b).

\subsection{Carbon, nitrogen and protein contents}

The present study was undertaken by Rodriguez et al. (2015c) to determine carbon and nitrogen content among 40 plant species of diverse growth habit with a view to select species with high carbon fixation (carbon content) and nitrogen content. In this study, few species were selected with high carbon fixation such as Eugenia caryophyllata (51.66\%), Litsea glauscensens (51.54\%), Rhusvirens (50.35\%), Gochantia hypoleuca (49.86\%), Pinus arizonica (49.32\%), Eryobotrya japonica (47.98\%), Tecoma stans (47.79\%), Rosamarinus officinalis $(47.77 \%)$. Few of these species could be recommended for plantation in $\mathrm{CO}_{2}$ polluted areas to reduce carbon load. In addition these, high carbon concentration could serve as good source of energy. We selected few species with high nitrogen content such as Mimosa malacophylla (8.44\%), Capscicum annuum (6.84\%), Moringa oleifer (6.25\%), Azadirachta indica (5.85\%), Eruca sativa (5.46\%), Rosamarinus officinalis (5.40\%), Mentha piperita (5.40\%). These species could serve as good sources of nitrogen for health care. We selected few species with high $\mathrm{C} / \mathrm{N}$ ratio such asArbutus xalapensis (26.94\%), Eryngium heterophyllum (24.29\%), Rhus virens (22.52\%), Croton suaveleons (20.16\%), Cinnamomum verum (19.89\%) which may be related to high production of secondary metabolites and antioxidants (Maiti et al., 2016-American Academic Press in press)

Maiti et al. (2016e) suggested adaptive morpho-physiological traits of woody plants for co-existence in a forest ecosystem.

It is discuseed that woody plants being dominant vegetation in a forest ecosystem of semiarid Mexico poseesss specific morphoanatomical, ecophysiological and biochemical traits for adaptation in the semi-arid environments with special refrence to hot summer and cool winter, similar to the environments prevalent in Mediterranean climates.

The paper putforward few hypothetical concepts for co-existence and adaptation of woody plant species in a Tamaulipan Thorn Scrub, Northeastern Mexico.The hypotheses have been putforwarded on the basis of our results on various morphological, anatomical and ecophysiological traits of A Tamaulipan Thorn Scrub, Northeastern Mexico. Few future research lines are suggested to confirm the hypotheses.

\section{References}

Rodriguez, H.G, Maiti, R.K., Tijerina, H.A.D., Gonzalez, M.I.1., Diaz, J.C.G., Kumari, A., 2015c. Variation in leaf traits of 34 trees and shrubs in summer season in linares, North-Eastern Mexico. International Journal of Bio-resource and Stress Management 6(6), 707-718. DOI: $10.5958 / 0976-4038.2015 .00109 .8$

Rodriguez, H.G., Maiti, R.K., 2015b. Phenology (flowering and fruiting) of ten woody plants in Linares, Mexico, International Journal of Bio-resource and Stress Management 6(4), 438-446.

Hickey, L.J., 1971. Evolutionary significance of leaf architectural features in the woody dicots. American Journal of Botany 58, 469.

Maiti, R.K., Rodriguez, H.G., 2015c. Mysetry of coexistence and adaptation of trees in a forest ecosystem. Forest Research 4(4), e120. http://dx.doi.org/10.4172/2168$9776.1000 \mathrm{e} 120$

Maiti, R.K., Para, A.C. Rodriguez, H.G., Paloma, S.V., $2015 f$. characterization of wood fibres of scrubs and tree species of the tamaulipan thornscrub, northeastern Mexico and its Possible Utilization. Forest Research, 4(4), 154. http:// dx.doi.org/10.4172/2168-9776.1000154

Maiti, R.K, Rodriguez, H.G., Gonzalez, E.A., Kumari, A., Sarkar, N.C., 2015g. Variability in epicuticular wax in 35 woody plants in linares, northeast Mexico. Forest Research 5(1), http://dx.doi.org/10.4172/21689776.1000162.

Maiti, R.K., Rodriguez, H.G., Kumari, A., 2016c. Nutrient profile of native woody species and medicinal plants in northeastern Mexico: A Synthesis. Journal of Bioprocessing \& Biotechniques 6, 283. doi:10.4172/21559821.1000283

Maiti, R.K., Rodriguez, H.G., Kumari, A., 2016a. Adaptive morpho-physiological traits of woody plants for coexistence in a forest ecosystem. Forest Research 5, 175. doi: 10.4172/2168-9776.1000175

Maiti, R.K., Rodriguez, H.G., Sarkar, N.C., Kumari, A., 2016 d. Biodiversity in leaf chemistry (pigments, epicuticular wax and leaf nutrients) in woody plant species in northeastern Mexico, a synthesis. Forest Research 5, 170. doi:10.4172/2168-9776.1000170.

Maiti, R.K., Rodriguez, H.G., Kumari, A., Diaz, J.C.G., 2015d. perspectives of branching pattern and branching density in 30 woody trees and shrubs in tamulipan thornscrub, Northeast of Mexico. Forest Research 4, 4. doi:10.4172/2168-9776.1000160

Maiti, R.K., Rodriguez, H.G., 2015d. Wood anatomy could 
predict the adaption of woody plants to environmental stresses and quality of timbers. Forest Research 4, 4 Doi:10.4172/2168-9776.1000e121

Maiti, R.K., Rodriguez, H.G., 2015b. Eco-physiologically highly efficient woody plant species in northeastern Mexico. Forest Research 4, 4. doi:10.4172/2168$9776.1000 \mathrm{e} 122$

Maiti, R.K., Rodriguez, H.G., 2015a. Phenology, morphology and variability in pollen viability of four woody trees (Cordia boissieri, Parkinsonia texana, Parkinsonia aculeate and Leucophyllum frutescens exposed to environmental temperatures in Linares, Northestern Mexico. Forest Research doi:1016.4172/2168.9776. SI-002.

Maiti, R.K., Rodriguez, H.G., Sarkar, N.C., Thakur, A.K., 2015e. Branching pattern and leaf crown architecture of some tree and shrubs in northeast Mexico. International Journal of Bio-resource and Stress Management 6(1), 041-050. doi:10.5958/0976-4038.2015.00009.

Maiti, R.K., Rodriguez, H.G., Natalya S.I., 2016e. Autoecology and Ecophysiology of Woody Shrubs and Trees. ISBN: 9781119104445. John Wiley and Sons, Ltd, 331.

Maiti, R.K., Rodriguez, H.G., Kumari, A., 2016f. Applied biology: a model. American Academic Press, 359.

Maiti, R.K., Rodriguez, H.G., Karfakis, T.N.S.. 2014a. variability in leaf canopy architecture may be related to photosynthetic efficiency and carbon fixation. International Journal of Bio-resource and Stress Management 5(4), 20-25. DOI:4343543.11212.

Maiti, R.K., Rodriguez, H.G., Mermolejo, J., Gonzalez, M.I.L., 2015h. Venation pattern and venation density of few native woody species in Linares, Northeast of Mexico. International Journal of Bio-resource and Stress Management, 6(6), 719-727. DOI: 10.5958/09764038.2015.00110.4.

Maiti, R.K., Rodriguez, H.G., Karfakis, T.N.S., 2014b. Variability in leaf traits of 14 native woody species in semiarid regions of northeastern Mexico. IJBSM 5(4), 5958/0976-4038.2014.00604.6. 